\title{
癌を合併した鼻副鼻腔乳頭腫例の検討
}

\author{
楯谷 智子 ${ }^{1)}$ - 北村 溥之 $2^{2)}$ - 庄司 和彦1) - 高北 晋一1) \\ 岩橋 由佳 ${ }^{3)}$ ・鈴木 慎二 ${ }^{1)} \cdot$ 河田 恭孝 ${ }^{1)} \cdot$ 宮崎 眞和 ${ }^{4}$

\section{Clinical Study of Carcinoma Associated with Papilloma of the Nasal Cavity and Paranasal Sinuses}

\author{
Tomoko Tateya, Kazuhiko Shoji, Shin-ichi Takagita, \\ Shinji Suzuki and Yasutaka Kawata \\ (Tenri Hospital) \\ Hiroyuki Kitamura \\ (Takai Hospital) \\ Yuka Iwahashi \\ (Shimane Prefectural Central Hospital) \\ Masakazu Miyazaki \\ (National Cancer Center Hospital East)
}

Thirty-nine cases of nasal and paranasal papilloma treated in Tenri Hospital during the last 20 years were reviewed. In 6 cases (15\%), squamous cell carcinoma was accompanied by papilloma and all were inverted papilloma. Two were male and 4 were female. The mean patient age in these 6 malignant cases was 73 years old, which was 13 years older than that in benign cases. In the 6 malignant cases, the lesions tended to be more extensive and more often involved the frontal sinus or sphenoid sinus than lesions in benign cases. Clinical symptoms and bone destruction in radiographic studies did not clearly characterize the existence of malignancy.

Three cases were preoperatively diagnosed as carcinoma and were treated with a combination of surgery, irradiation and chemotherapy. The other cases were diagnosed as carcinoma from surgically obtained materials and two received postoperative radiotherapy while one case did not. The 3 -year survival rate was $80 \%$.

Key words : carcinoma, nasal and paranasal papilloma, postoperative radiotherapy

はじめに

鼻副鼻腔乳頭腫は病理学的には良性腫瘍であるが，再 発が多く癌が比較的高頻度に合併することが知られてい る. 癌が合併している場合，速やかに診断を下し適切な 治療を行うことが必要であり, そのためには癌を合併し
た乳頭腫の臨床像を知ることが重要であるが，本邦にお ける癌合併例の臨床像に関する詳細な報告は多くな い1).今回われわれは，癌を合併した鼻副鼻腔乳頭腫の 臨床的特徴を把握することを目的に，当科で経験した過 去20年間の鼻副鼻腔乳頭腫につき検討を行ったので報告

2) 高井病院耳鼻咽喉科

4）国立がんセンター東病院頭頸科
1）天理よろづ相談所病院耳鼻咽喉科

3）島根県立中央病院耳鼻咽喉科 
する.

\section{対象および方法}

対象は, 1981 年 1 月から 2000 年 12 月までの 20 年間 に当科で手術治療を行い, 6 力月以上経過観察を行った鼻 副鼻腔乳頭腫 39 例である. このうち癌合併例は 6 例 (15 \%）であった．癌合併例につき，外来および入院診療記 録に基づき，初診時年齢，性別，病理組織学的分類，自 覚症状, 画像所見, 占拠部位, 治療法, 再発について調 べた。癌合併群と癌非合併群を比較した際の統計学的検 討は， $\mathrm{t}$ 検定，Fisher の直接確率計算法または $\mathrm{G}$ 検定を 用い, $\mathrm{t}$ 検定以外の検定方法は $\mathrm{P}$ 值の後に示した。

\section{結果}

1）年齢および性

鼻副鼻腔乳頭腫 39 例の初診時平均年齢は 62 歳であっ た．癌非合併群と癌合併群の 2 群間で比較すると, 癌非 合併群は平均 60 歳であるのに対し, 癌合併群は 73 歳で あり, 癌合併群の方が有意に高齢であった $(\mathrm{P}<0.05)$.

また，鼻副鼻腔乳頭腫 39 例のうち男性は 28 例，女性 は 11 例であり，男女比は約 $2.5: 1$ であった。癌非合併 群は 33 例中男性 26 例, 女性 7 例であり, 男女比約 $4: 1$ であるのに対し，癌合併群 6 例は男性 2 例，女性 4 例， 男女比 $1: 2$ であった。癌合併群の方が有意に女性が多 かった $(\mathrm{P}<0.05$, Fisher の直接確率計算法 $)$.

2) 病理組織学的分類

鼻副鼻腔乳頭腫に合併した 6 例の癌は，すべて中・高 分化型扁平上皮癌であった. なお, 1981 年 1 月から 2000 年 12 月までの 20 年間に当科で治療を行った鼻副鼻腔扁 平上皮癌は，この 6 例の癌・乳頭腫合併例を含めて合計 36 例あり, 鼻副鼻腔扁平上皮癌のなかでの鼻副鼻腔乳頭 腫の合併頻度は $17 \%$ であった。

鼻副鼻腔乳頭腫は病理組織学的に内反性乳頭腫と外反 性乳頭腫に分類されるが, 内反性乳頭腫が 33 例, 外反性 乳頭腫は 6 例であった。 そのうち 2 例は一部内反性乳頭 腫が混在していたが，外反性乳頭腫が優勢であったため 外反性乳頭腫に含めた。 発育形態別にみた癌合併頻度は, 内反性乳頭腫が $18 \%$ ，外反性乳頭腫が $0 \%$ であり，癌合 併群はすべて内反性乳頭腫例であった（表 1).

乳頭腫の癌化の定義は「(1) 全くの良性の乳頭腫であっ たものが再発時に癌と診断されたもの，(2) 初回の病理 標本において乳頭腫と癌が混在し，しかも両者の間に移
表 1 病理組織学的分類と癌合併頻度

\begin{tabular}{llr|r}
\hline \hline & 癌合併群 & 癌非合併群 & \multicolumn{1}{c}{ 計 } \\
\hline 内反性乳頭腫 & 6 例 $(18 \%)$ & 27 例 $(82 \%)$ & 33 例 \\
外反性乳頭腫 & 0 例 $(0 \%)$ & 6 例 $(100 \%)$ & 6 例 \\
\hline & 6 例 & 33 例 & 39 例
\end{tabular}

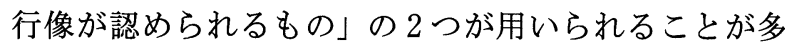
(2) 4) が，この定義に従うと，自験例では乳頭腫の癌 化と判定されたのは 6 例中 4 例であり,すべて定義の (2) が当てはまる症例であった。

3）自覚症状（図 1)

癌合併の有無別に自覚症状を検討した結果を図 1 に示 す。癌非合併群では，一側性鼻閉を訴えた症例が $79 \%$, 鼻漏 $27 \%$, 鼻出血 $6 \%$, 煩部腫脹 $3 \%$, 煩部痛 $3 \%$ であっ た。癌合併群では，鼻閉 $67 \%$, 鼻漏 $50 \%$, 鼻出血 $17 \%$, 㚘部腫脹 $17 \%$ ，煩部痛 $0 \%$ であった，両群間で有意差は 認められなかった。

4）画像上骨欠損

X線写真またはCT等画像所見上で骨欠損がみられた割 合は, 癌非合併群で 8 例 (24\%), 癌合併群で 4 例 (67 \%) であった，癌合併例の方が頻度は高かったが，有意 差は認められなかった。

5）進展範囲（表 2)

腫瘍が鼻腔内に限局していた症例は，癌非合併群 10 例，癌合併群 0 例であり，腫瘍が上顎洞または節骨洞ま で進展した症例は, 癌非合併群 18 例, 癌合併群 2 例であ り，腫瘍がさらに前頭洞または蝶形骨洞に及ぶ症例は， 癌非合併群 5 例, 癌合併群 4 例であった．両群間で比較 すると，癌合併例では有意に腫瘍は広範囲に進展してい た $(\mathrm{P}<0.05, \mathrm{G}$ 検定 $)$.

6）術前診断と治療

癌合併 6 例につき，各症例の腫瘍全体の進展範囲およ び癌の進展範囲を表 3 に示す。

治療開始前に内反性乳頭腫と癌の合併という診断がつ いたのは症例 $1 \sim 3$ の 3 例であった. 症例 1,2 は, 鼻腔 からの生検で内反性乳頭腫と癌の合併といら診断がつい たが，いずれも腫瘍が広範囲に及ぶ進行例であった。症 例 1 は当初手術不能と考えられたが放射線・化学療法に より腫瘍の縮小がみられ，摘出可能となったため側鼻切 開術により摘出した。症例 2 は上顎拡大全摘術を行った が, 癌の残存が疑われたため術後照射 $60 \mathrm{~Gy}$ を併用した。 


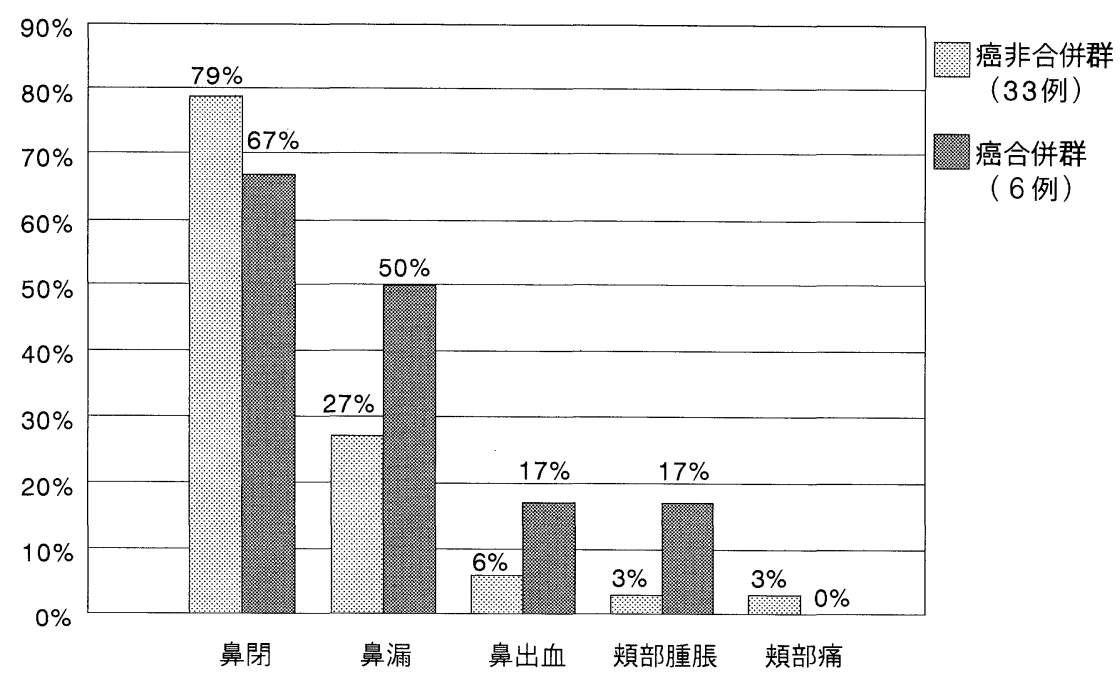

図 1 自覚症状 癌合併の有無による比較

表 2 腫瘍の進展範囲一癌合併の有無による比較一

\begin{tabular}{lccc}
\hline \hline \multicolumn{1}{c}{ 進展範囲 } & 癌非合併群 & 癌合併群 \\
\hline 1）鼻腔内に限局 & 10 例 & 0 例 \\
2) 上頇洞，篩骨洞まで進展 & 18 例 & 2 例 \\
$3 ）$ 前頭洞，蝶形骨洞まで進展 & 5 例 & 4 例
\end{tabular}

症例 3 は鼻腔からの生検では内反性乳頭腫であったが, 煩部腫脹があり, かつ CT で骨欠損像を認めたため, 癌 を疑って上顎洞試験開洞が施行された. その時に癌と確 定診断され，三者併用療法（浅側頭動脈からの 5-Fu 動 注, Denker 手術による腫瘍減量と術後の择爬, 照射 $50 \mathrm{~Gy}$ の併用）を施行した.

症例 $4 \sim 6$ の 3 例は, 術前診断は内反性乳頭腫として 手術が行われ, 術後の病理組織診断で癌と診断された. 症例 4 は主病変が上顎洞にあったため Denker-和辻法, 症例 5 は病変が前頭洞・篩骨洞にあったため Killian 切開 による前頭洞笠骨洞腫瘍摘出術を施行した ${ }^{5)}$. 症例 6 は, 腫瘍が有茥性であったため鼻内内視鏡により完全摘出し 得た. これらの 3 例は術後に追加手術は行っておらず, 症例 4,5 は術後照射 $50 \mathrm{~Gy}$ を施行した. 症例 6 は, 家族 の強い希望で術後照射等の追加治療は行わなかった.

以上 6 例は, 全例初回治療時に癌の合併が診断されて おり, 乳頭腫の再発時に癌化を認めた症例はなかった. また, 全例初回治療時に頸部リンパ節転移・遠隔転移を 認めなかった。

7）再発と予後
鼻副鼻腔乳頭腫 39 例の術後観察期間は 6 カ月〜 12 年 7 力, 平均 4 年 1 カ月であった. また, 癌合併群 6 例の 術後観察期間は 7 カ月〜 4 年 1 力月, 平均 2 年 0 力月で あった。

乳頭腫の再発がみられたのは, 癌非合併群で 9 例 $(27$ $\%)$, 癌合併群で 2 例 (33\%) であり, 乳頭腫の再発につ いては差がみられなかった。

癌合併群のうち症例 1,2 の 2 例に癌の局所再発が認め られた. 症例 1 は 1 年 4 力月後に乳頭腫が再発したため 鼻内内視鏡手術を施行し, その 7 カ月後の再々発時には 乳頭腫と癌が鼻腔上方〜前頭洞に再発した. 腫瘍摘出術 を行ったが, 癌の残存が疑われたため術後照射 $30 \mathrm{~Gy}$ お よび化学療法を行った. 現在経過観察中であり再発を認 めていない. 症例 2 は術後 11 カ月で癌が局所再発し死亡 した. ほかの 4 例は非担癌生存している. Kaplan-Meier 法による鼻副鼻腔乳頭腫と癌の合併例の 3 年生存率は 80 \%であった.

\section{考按}

鼻副鼻腔乳頭腫の癌合併の割合は諸家の報告により異 なるが, $1.2 \sim 24 \%$ と報告されている1) 3)6). 自験例も 15\%でありその範囲内であった.

Norris $^{7)}$ は鼻副鼻腔乳頭腫を病理組織学的に inverted papilloma（内反性乳頭腫）, exophytic papilloma（外反性 乳頭腫）の 2 群に分類し, 内反性乳頭腫の方が癌を合併 しやすいなど臨床的特徴に相違があると報告した. 以後 
表 3 癌合併例の腫瘍および癌の進展範囲, 診断と治療

\begin{tabular}{|c|c|c|c|c|c|c|}
\hline 症例 & 腫瘍の進展範囲 & 癌の進展範囲 & $\begin{array}{c}\text { 術前診断 } \\
\text { (鼻腔からの生検) }\end{array}$ & 癌の診断 & 手術 & $\begin{array}{l}\text { その他 } \\
\text { 治療 }\end{array}$ \\
\hline 1 & $\begin{array}{l}\text { 右箵骨洞 右蝶形骨洞 右鼻腔 } \\
\text { 頭䓝底・右眼窩浸潤あり** }\end{array}$ & $\begin{array}{l}\text { 右穊骨洞** } \\
\text { 右鼻腔 }\end{array}$ & $\begin{array}{l}\text { 内反性乳頭腫 } \\
\text { 扁平上皮癌 }\end{array}$ & 術前生検 & 側鼻切開 & 術前 $40 \mathrm{~Gy}$ - 化学療法 \\
\hline 2 & 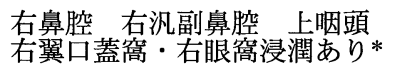 & 同左 & $\begin{array}{l}\text { 内反性乳頭腫 } \\
\text { 扁平上皮癌 }\end{array}$ & 術前生検 & 上顎拡大 全摘 & 術後 60 Gy \\
\hline 3 & 右上顎洞＼cjkstart右鼻腔 & 右上顎洞** & 内反性乳頭腫 & 試験開洞 & Denker-和辻 & 三者併用療法 \\
\hline 4 & 右上䫟洞 右鼻腔 & 右上顎洞 & 内反性乳頭腫 & 手術 & Denker-和辻 & 術後 50 Gy \\
\hline 5 & 右前頭洞＼cjkstart右笁骨洞＼cjkstart右鼻腔 & 右前頭洞 & 内反性乳頭腫 & 手術 & Killian & 術後 50 Gy \\
\hline 6 & 右蝶形骨洞 右鼻腔 上咽頭 & 右蝶形骨洞 & 内反性乳頭腫 & 手術 & 鼻内内視鏡 & なし \\
\hline
\end{tabular}

* 画像による進展範囲（その他沭中所見による）

**術前照射後の癌の残存部位

癌合併例につき発育形態別に検討されることも多く, 癌 合併頻度は内反性乳頭腫が $3 \sim 32 \%{ }^{8}$, 外反性乳頭腫が $0 \sim 4 \%{ }^{9)}$ とされている. 自験例でも癌合併頻度は内反性 乳頭腫が $18 \%$, 外反性乳頭腫が $0 \%$ と, 内反性乳頭腫例 にのみ癌の合併がみられた。

初診時年齢は，自験例では癌合併例は非合併例より平 均 13 歳高齢であった. Weissler ら ${ }^{10)}$ は平均 13 歳, 石橋 ら ${ }^{1)}$ は平均 13.7 歳高齢であったと報告しており, 自験例 と同様の結果であった．高齢者は癌合併の高危険群と考 えられた. 今回の調查では病悩期間については検討して いないが，癌合併例が高齢である理由の一つとして，経 過が長い症例の方が癌化が起こりやすい可能性が考えら れる。

乳頭腫全体の男女比は, 自験例では $2.5: 1$, 癌合併例 は男女比は $1: 2$ であり, 女性が有意に多かった. Snyder ら ${ }^{6)}$ の報告では乳頭腫全体では男女比は $3: 1$, 癌合併例 は男女比 $1: 1$ であり, 乳頭腫全体に比べると癌合併例は 女性の割合が高かった。しかし, 癌合併例は明らかに女 性が多いといら報告は渉猟し得た限りではなかった。こ の点に関してはより多数例での検討が必要と考えられ た.

癌を合併した鼻副鼻腔乳頭腫症例に鼻出血や疼痛など 特徴的な症状があるかどうかについては否定的な意見が 多(1110). 自験例においても, 癌を合併していない乳頭 腫であっても鼻出血や煩部痛など鼻副鼻腔悪性腫瘍を疑 わせる症状を示す症例があり, 症状では癌合併例に有意 に特徴的なものはなかった。

$\mathrm{X}$ 線写真上明らかな骨破壊像を認める場合は癌を合併
する例が多いとされる1)，自験例においても画像上の骨 欠損については, 有意差はなかった $(\mathrm{P}=0.06)$ ものの, 癌非合併例に比べ癌合併例で高頻度に認められる傾向が あった.しかし, 癌を合併した 6 例のうち 2 例は術前 CT でも骨破壊像は認められなかった。 また，術前に鼻腔か らの生検で癌との診断ができたのは, 自験例では 6 例中 2 例のみであった。乳頭腫の一部に癌を合併している場 合, 鼻腔からの生検では癌を含む組織を採取できないこ とがあると思われる．癌合併の有無の判定には術後の腫 瘍全体にわたる病理組織学的検索が必要であり, 術前の 画像所見や鼻腔からの生検では癌の合併を確定診断する のは難しいと考えられた.

自験例では癌合併例は前頭洞・蝶形骨洞に進展してい るものに多かったが，その理由としては，前頭洞・蝶形 骨洞に進展しているものは乳頭腫自体が大きく経過が長 いと考えられ，そのような腫瘍の方が癌化が起こりやす い可能性があるということと, 癌を合併しているために 増大が早く，見つかったときには大きくなっている可能 性があるといらことの 2 つが考えられる.いずれにせよ， 腫瘍が広範囲であるものはより強く癌の合併を疑うべき である.

鼻副鼻腔乳頭腫治療は手術による完全摘出が原則であ るが，癌を合併していれば腫瘍摘出術だけでは不十分と 考えられる. 治療開始前に癌と診断のついた 3 例には, 症例に応じて手術と放射線・化学療法を組み合わせた集 学的治療が行われており, 術前診断は内反性乳頭腫とし て手術が行われ, 術後の病理組織診断で癌と診断された 3 例には, 放射線治療拒否例を除き術後照射が追加され 
た.

癌合併例の予後は, 術後平均経過観察期間が 2 年と短 いものの, 3 年生存率は $80 \%$ であり比較的良好であった. 放射線治療を併用することで良好な生命予後が得られる と考えられる.

鼻腔からの生検で乳頭腫という診断であった 4 例は再 発なく予後良好であったが，症例 3 以外の 3 例は術前情 報からは癌を疑わず，術後初めて癌と判明した症例で あった.このような症例をどう扱うか, 少数例の成績で 治療方針について確定的な見解を述べるのは無理がある があえて考察してみると，このような症例は比較的予後 良好であり, 腫愓摘出が完全と考えられるならば拡大手 術の追加は侵襲が大きすぎるように思われる．しかし良 性腫瘍として手術しているので癌としては断端は不十分 である可能性があり，したがって術後照射を行うのが適 当と考える.

\section{まとめ}

1）鼻副鼻腔乳頭腫 39 例のうち，6 例 $(15 \%)$ に癌の 合併が認められ，すべて内反性乳頭腫と扁平上皮癌の合 併であった。

2）癌合併例は非合併例に比へ，高齢者，女性に多く， 前頭洞・蝶形骨洞を含む広範囲な腫瘍に多かった。

3）自覚症状，画像所見には，癌合併例に特徴的なもの はなかった。

4） 3 年生存率は $80 \%$ と比較的良好であった.術後の病 理組織診断で初めて癌と診断された症例に対しては, 術 後照射を併用すれば良好な予後が期待できると考えられ た.

\section{参考文献}

1）石橋敏夫，野村恭也，井上憲文 : 鼻副鼻腔の乳頭腫. 日耳 鼻 $90 ： 1927 \sim 1932 ， 1987$.

2) Osborn DA : Nature and behavior of transitional tumors in the upper respiratory tract. Cancer $25: 50 \sim 60,1970$.

3) Lasser A, Rothfeld PR and Shapiro RS : Epithelial papilloma and squamous cell carcinoma of the nasal cavity and paranasal sinuses; a clinicopathological study. Cancer 38: $2503 \sim 2510$, 1976.

4) Myers EN, Schramm VL Jr. and Barnes EL Jr. : Management of inverted papilloma of the nose and paranasal sinuses. Laryngoscope $91: 2071 \sim 2084,1981$.

5）宮崎眞和, 韓 相善, 北村溥之, 他 : 扁平上皮癌を伴った 前頭洞内翻性乳頭腫例. 耳鼻臨床 $91 ： 35 \sim 38,1998$.

6) Snyder RN and Perzin KH : Papillomatosis of nasal cavity and paranasal sinuses (inverted papilloma, squamous papilloma); a clinicopathological study. Cancer 30:668 690, 1972.

7) Norris HJ : Papillary lesions of the nasal cavity and paranasal sinuses. Part II: inverted papillomas. A study of 29 cases. Laryngoscope $73: 1 \sim 17,1963$.

8）古田 康, 田中克彦, 本村昌一, 他 : 鼻 - 副鼻腔の内反性 乳頭腫一特に癌合併例, 癌化例について一. 耳喉 $58: 1057$ 〜 1064, 1986.

9) 碓井康子：鼻・副鼻腔乳頭腫症 19 例の臨床病理学的検討. 日耳鼻 $87: 665 \sim 673,1984$.

10) Weissler MC, Montgomery WW, Turner PA, et al. : Inverted papilloma. Ann Otol Rhinol Laryngol 95 : $215 \sim 221,1986$.

原稿受付：平成 14 年 1 月 28 日

原稿採択 : 平成 14 年 5 月 22 日

別刷請求先 : 楯谷智子

厂524-8524 守山市守山5-4-30

滋賀県立成人病センター耳鼻咽喉科 